\title{
INTENSIVE ELECTRO SINTERING OF DIAMOND COMPOSITES WITH MULTICOMPONENT Ni-Sn BASED BINDER
}

\begin{abstract}
This paper deals with intensive electro sintering (IES) of diamond composite materials (DCM) with multicomponent Ni-Sn based binder. The effect of the powder mixture composition, activating dopants and IES technical parameters on the formation of the microstructure and physical, and mechanical properties of DCM is studied. It has been established that the leading densification mechanisms of IES involve thermally activated plastic deformation of nickel powder particles, tin melting, and infiltration and chemical interaction of components. The presence of a liquid phase during the electro sintering increases conductivity of powder compact and intensity of heating which, in turn, significantly increases shrinkage rate and promotes uniform distribution of components and formation of intermetallic compounds. The macro-kinetic model of intermetallic compounds formation in the NiSn system in non-isothermal conditions and the model of DCM with structured matrix and imperfect interface have been developed. The thermal and mechanical properties of electro sintered DCM have been evaluated. The initial mixture composition and the IES technological parameters promising in terms of DCM quality have been found. The proposed method of manufacturing the drilling bits by IES constitutes a potential basis for the industrial production technology of diamond tools.
\end{abstract}

Keywords: diamond composites, shrinkage, sintering, thermal conductivity

\section{Introduction}

The conventional powder metallurgy methods of diamond composite materials (DCM) production for tool applications are vacuum sintering, hot pressing and infiltration. The inherent feature of these and related technologies is quite a long exposure at high $\left(>1000^{\circ} \mathrm{C}\right)$ temperature. So high thermal loading provokes diamond cracking and/or graphitization already at the stage of DCM production,

\footnotetext{
${ }^{1}$ Autor do korespondencji/corresponding author: Roman Shmegera, Institute for Superhard Materials of the National Academy of Sciences, Kyiv, Ukraine, e-mail: shmegerar@ukr.net

2 Volodymyr Kushch, V.Bakul Institute for Superhard Materials of the National Academy of Sciences, Kyiv, Ukraine, e-mail: vkushch@bigmir.net
} 
which results in reducing their physical, mechanical and performance properties. Improvement of DCM quality can be achieved by significant lowering the temperature and reducing the sintering time as well as by formation of the reliable chemical or adhesive bond between the diamonds and matrix.

The above requirements are met by the intensive electro sintering (IES) technology [1] which consists in passing the electric current through the highly loaded (up to $500 \mathrm{MPa}$ ) powder compact. IES is regarded as a promising alternate DCM production technology because its $p T$-parameters allow to avoid degradation of diamond and thus improve the quality of the diamond tools. In addition, the small localized heating zone and transience of the process reduce energy consumption by an order in comparison with the conventional technologies. Currently, practical use of IES is limited to DCM with one-component binders, whose tensile strength and fracture toughness is insufficient for drilling tool applications. A highly promising - but still practically unexplored - area is intensive electro sintering of DCM with multicomponent binder including the activating and alloying additives. However, practical implementation of the advantages of this technology requires development of new, optimized for IES technology DCM binders, study of consolidation patterns and structure formation and their effect on the DCM physical, mechanical and performance properties.

\section{Experimental study}

It has been shown recently [2] that the Ni-Sn based alloys have a great potential as the IES-oriented DCM binder. The main component of this binder ( $>$ $50 \%$ ) is nickel which, in contrast to iron and cobalt, retains considerable plasticity in the doping and is resistant to oxidation that enables sintering without a protective atmosphere. In addition, nickel at $700^{\circ} \mathrm{C}$ and above interacts actively with diamond by creating a reliable adhesive contact. The main activating element is tin (up to 15\%), which provides electro sintering in the presence of liquid phase and gives, as a result of chemical reaction with the other components, intermetallic compounds that increase hardness and wear resistance of binder. Its durability can be further increased by filling in a certain amount (15-20\%) of powder of refractory compounds ( $\mathrm{WC}, \mathrm{TiC}, \mathrm{TiB}_{2}$, etc.). Adding chromium known to be an effective carbide former is intended to improve diamond-tomatrix bonding. For manufacturing the samples, the nickel and tin powders and synthetic diamonds ACT200 400/315 were mixed in a rattler with hard metal balls in dry grinding mode for 8 hours. The powder mixture was compacted by two-sided cold pressing by pressure of $300 \mathrm{MPa}$ resulting in porosity of compacts around $40 \%$. The intensive electro sintering of samples was carried out by passing the current density of $25 \mathrm{~A} / \mathrm{mm} 2$ with applying pressure of $150 \mathrm{MPa}$.

The time-dependent parameters of IES, for example current density (fig. 1) and shrinkage (fig. 2) of DCM binder demonstrate that sintering in the presence of a limited amount of liquid phase (curve 2) differs significantly from solid 
state sintering (curve 1). The presence of tin in the mixture provides the appearance of a liquid phase already in the early stage of sintering, resulting in a significant increase in the conductivity of the sample. In turn, this leads to more intensive heating and significant intensification of shrinkage and chemical reactions with formation of the intermetallic compounds. Noteworthy, shrinkage of porous compact begins with some delay ( $3 \mathrm{~s}$ for nickel, and 6 seconds for mixture, fig. $2)$. This is because the axial pressure of cold pressing $(300 \mathrm{MPa})$ is higher than the pressure during sintering Therefore, plastic flow being the main densification mechanism is activated only when the macroscopic yield strength of porous solid was reduced sufficiently under the action of temperature. Among the possible causes of greater time delay in a case of a powder mixture is that tin facilitates consolidation during the cold pressing resulting in the lower porosity and hence higher yield strength of compact. It is also likely that the transition of one of the components in the liquid phase absorbs a certain amount of heat, thus slowing down the heating process and delaying the start of shrinkage.

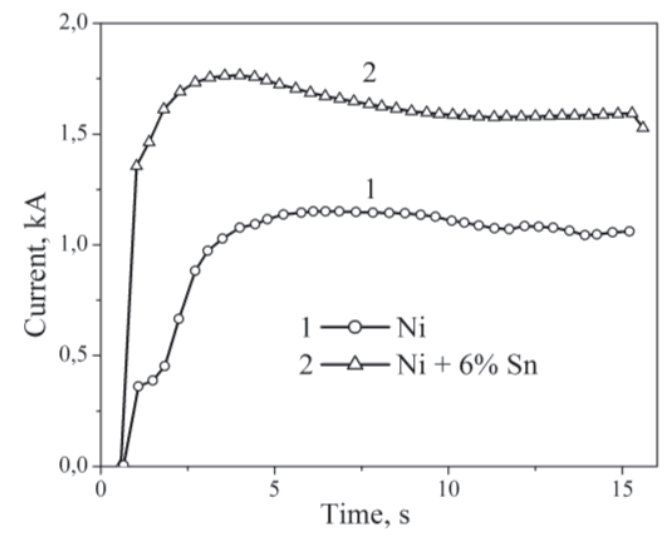

Fig. 1. Current density as a function of time

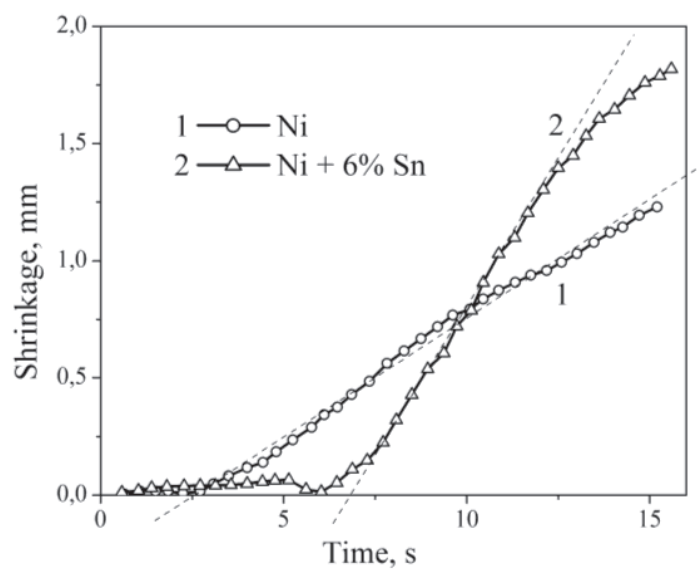

Fig. 2. Shrinkage as a function of time 
This, the experimental study proves IES as a highly efficient method of manufacturing the DCM with Ni-Sn binder providing full consolidation of powder compacts for tens of seconds at the sintering temperature below $850^{\circ} \mathrm{C}$ thus maintaining the original quality of diamonds. The leading densification mechanisms of IES are thermally activated plastic deformation of the nickel powder, tin melting/infiltration and chemical reactions between the components. Presence of a limited amount of liquid phase during the electro sintering significantly increases electrical conductivity of compact and thus intensity of heating and shrinkage rate and also facilitates uniform distribution of components and formation of intermetallic compounds.

\section{Macro-kinetic model}

The fundamentally important parameter is the time of sintering. For reasons of preserving high quality of diamonds it should be the lowest possible but, at the same time, sufficient for the heterogeneous microstructure formation as a result of chemical reactions. According to the Ni-Sn binary phase diagram (e.g., $[3,4]$ ), formation of $\mathrm{Ni}_{3} \mathrm{Sn}_{4}, \mathrm{Ni}_{3} \mathrm{Sn}_{2}$ and $\mathrm{Ni}_{3} \mathrm{Sn}$ intermetallics during sintering is expected. The experimental data (e.g., [5, 6]) and theoretical models $[7,8]$ of the $\mathrm{Ni}$-Sn intermetallics formation are available only for the case of isothermal conditions and solid samples. The only paper [9] is available where mixture of nickel and tin powders was studied. It has been found there that heating the mixture to $300^{\circ} \mathrm{C}$ followed by exposure leads to the formation of all three intermetallic compounds, but no quantitative data were reported.

To describe/predict the process of intermetallics formation in the rapidly heated Ni-Sn powder mixture, the macro-kinetic model has been formulated under the assumption that the rate of each reaction depends on the temperature and concentration by Arrhenius law and the law of mass action, respectively. To account for the diffusive nature of all stages and "braking" the reaction rate by increasing product layer the appropriate braking parameters were introduced. In particular, for $\mathrm{Ni}+12 \% \mathrm{Sn}$ the model predicts completing the reactions in 30 seconds at $900^{\circ} \mathrm{C}$ while at $800^{\circ} \mathrm{C}$ it takes above 5 minutes. The model has been experimentally verified and then applied to determine the optimum temperature and the time of sintering.

Among many possible chemical reactions in the Ni-Sn system [3, 4], we consider three most obvious and experimentally confirmed ones:

$$
\begin{aligned}
& 3 \mathrm{Ni}+4 \mathrm{Sn} \rightarrow \mathrm{Ni}_{3} \mathrm{Sn}_{4} ; \mathrm{Ni}_{3} \mathrm{Sn}_{4}+3 \mathrm{Ni} \rightarrow 2 \mathrm{Ni}_{3} \mathrm{Sn}_{2} \\
& \mathrm{Ni}_{3} \mathrm{Sn}_{2}+3 \mathrm{Ni} \rightarrow 2 \mathrm{Ni}_{3} \mathrm{Sn}
\end{aligned}
$$

We introduce notations for mass concentrations of reactants and products: 


$$
y_{1}=[N i] ; y_{2}=[S n] ; y_{3}=\left[N i_{3} S n_{4}\right] ; y_{4}=\left[N i_{3} S n_{2}\right] ; y_{5}=\left[N i_{3} S n\right]
$$

where $n$ is a number of substances involved in the reactions (in our case, 5). Each reaction is carried out based on the law of conservation of mass:

$$
\sum_{k=1}^{n} v_{k i} m_{k}=0(i=1, \ldots, r), \quad \sum_{k=1}^{n} y_{k}=1
$$

where $v_{k i}$ is the stoichiometric coefficient of component $k$ in the reaction $i$ (in our case, $r=3) ; m_{k}$ is its molar weight $[\mathrm{kg} / \mathrm{mol}]: m_{1}=58.69 \cdot 10^{-3} ; m_{2}$ $=118.71 \cdot 10^{-3} ; m_{3}=3 m_{1}+4 m_{2} ; m_{4}=3 m_{1}+2 m_{2}$ and $m_{5}=3 m_{1}+m_{2}$.

The formal kinetic equations are based on the standard balance equations where diffusion is taken into account as the slowest process that occurs at the level of individual particles and affects the formal kinetic laws. The balance equations take the form:

$$
\rho \frac{d y_{k}}{d t}=\omega_{k}
$$

where $\omega_{k}$ is a sum of sources and sinks of component $k$ in reactions:

$$
\omega_{k}=\sum_{i=1}^{r} m_{k} v_{k i} \Phi_{i}
$$

Here $\Phi_{i}$ is the reaction rate $\left[\mathrm{mol} /\left(\mathrm{m}^{3} \mathrm{~s}\right)\right]$ dependent on the concentrations by the law of mass action:

$$
\Phi_{1}=z_{1} y_{1}^{3} y_{2}^{4} ; \Phi_{2}=z_{2} y_{3} y_{1}^{3} ; \Phi_{3}=z_{3} y_{4} y_{1}^{3}
$$

where (see, e.g., [10]):

$$
z_{i}=z_{i 0} \exp \left(-\frac{E_{a i}}{R T}\right) \exp \left(-p_{i} y\right) y^{-s_{i}}
$$

$y=y_{2}+y_{3}+y_{4}$ is a fixed component which hinders diffusion of reactants to each other and withdrawal of products from the reaction zone, $z_{i 0}$ is the rate 
constant of reaction, $R$ is the universal gas constant, $T$ is the temperature and $E_{a i}$ is the activation energy of reaction. The braking parameters $p_{i}, s_{i}$ are usually determined from an experiment or found from the micro models which take into account the diffusion through the product layer and interface reactions between the particles of various size, etc. [11]. All the microscopic processes affect the values of constants $z_{i}$ which are measured in $\mathrm{mol} /\left(\mathrm{m}^{3} \mathrm{~s}\right)$. The explicit form of the system (4) is:

$$
\begin{aligned}
& \rho \frac{d y_{1}}{d t}=-3 m_{1}\left[\Phi_{1}+\Phi_{2}+\Phi_{3}\right] ; \rho \frac{d y_{2}}{d t}=-4 m_{2} \Phi_{1} ; \\
& \rho \frac{d y_{3}}{d t}=m_{3}\left[\Phi_{1}-\Phi_{2}\right] ; \rho \frac{d y_{4}}{d t}=m_{4}\left[2 \Phi_{2}-\Phi_{3}\right] ; \rho \frac{d y_{5}}{d t}=2 m_{5} \Phi_{3} .
\end{aligned}
$$

As an example, we conduct calculations for the powder mixture $\mathrm{Ni}+12 \% \mathrm{Sn}$ heated by some known law $T(t)$. At the beginning, composition of the powder mixture is given by the conditions:

$$
y_{1}=y_{10} ; \quad y_{2}=y_{12} ; \quad y_{3}=y_{4}=y_{5}=0 \text {. }
$$

To find the mass content of components variation over the time one needs to integrate the ordinary differential equations (8) with the initial conditions (9). The input material parameters reported below were taken from $[3,5,7,12] ; p_{i}=$ $10, s_{i}=0[10]$.

Table 1. Thermal properties of the Ni-Sn intermetallics

\begin{tabular}{|l|l|l|l|l|l|l|}
\hline Phase & $\begin{array}{l}T_{\text {melt, }}, \\
\mathrm{K}\end{array}$ & $\begin{array}{l}\rho, \\
\mathrm{g} / \mathrm{sm}^{3}\end{array}$ & $\begin{array}{l}C_{p}, \\
\frac{\mathrm{J}}{\mathrm{mol} \cdot \mathrm{K}}\end{array}$ & $\begin{array}{l}\frac{M}{\mathrm{~g}} \\
\mathrm{~mol}\end{array}$ & $\begin{array}{l}\mathrm{S}_{298}^{0}, \\
\frac{\mathrm{J}}{\mathrm{mol} \cdot \mathrm{K}}\end{array}$ & $\begin{array}{l}-\Delta H_{298}, \\
\frac{\mathrm{kJ}}{\mathrm{mol}}\end{array}$ \\
\hline $\mathrm{Ni}_{3} \mathrm{Sn}_{4}$ & 1057 & 8.42 & 160.3 & 650.9 & 257.7 & 177.3 \\
\hline $\mathrm{Ni}_{3} \mathrm{Sn}_{2}$ & 1538 & 9.02 & 108.7 & 413.5 & 173.6 & 156.9 \\
\hline $\mathrm{Ni}_{3} \mathrm{Sn}$ & 1250 & 9.49 & 99.6 & 294.8 & 131.4 & 93.7 \\
\hline
\end{tabular}

Table 2. Formal kinetic parameters of the reactions

\begin{tabular}{|c|c|c|c|}
\hline Reaction & $\begin{array}{c}S_{\text {reaction }}, \\
\mathrm{J} /(\mathrm{mol} \cdot \mathrm{K})\end{array}$ & $\begin{array}{c}E_{a}, \\
\mathrm{~J} / \mathrm{mol}\end{array}$ & $z_{i 0}, 1 / \mathrm{s}$ \\
\hline $3 \mathrm{Ni}+4 \mathrm{Sn} \rightarrow \mathrm{Ni}_{3} \mathrm{Sn}_{4}$ & -38.10 & 49060 & $7.217 \cdot 10^{11}$ \\
\hline $\mathrm{Ni}_{3} \mathrm{Sn}_{4}+3 \mathrm{Ni} \rightarrow 2 \mathrm{Ni}_{3} \mathrm{Sn}_{2}$ & -0.119 & 242670 & $5.87 \cdot 10^{9}$ \\
\hline $\mathrm{Ni}_{3} \mathrm{Sn}_{2}+3 \mathrm{Ni} \rightarrow 2 \mathrm{Ni}_{3} \mathrm{Sn}$ & -0.419 & 243300 & $5.686 \cdot 10^{9}$ \\
\hline
\end{tabular}


The system of equations (9) was solved by the Runge-Kutta method with variable in time temperature:

$$
T(t)=\left\{\begin{array}{c}
\left(T^{\prime} t-T_{0}\right) /\left(T_{\max }-T_{0}\right) t \leq t_{\max } \\
T=T_{\max }, t>t_{\max }
\end{array}\right.
$$

where $T_{0}$ is the initial temperature and $t_{\max }$ is the heating time to maximum temperature $T_{\max }$. Figure 3 shows the simulation results for the chemical reactions in $\mathrm{Ni}-\mathrm{Sn}$ system heated from 20 to $800^{\circ} \mathrm{C}$ (fig. 3(a)) and $900^{\circ} \mathrm{C}$ (fig. 3(b)) during 10 seconds with subsequent exposure. The model predicts a rapid decrease (almost zero) tin content at the stage of heating $\left(t_{\max }<10\right.$ seconds) to form intermetallic $\mathrm{Ni}_{3} \mathrm{Sn}_{4}$. However, at $t=t_{\max }$ we already have some amount of $\mathrm{Ni}_{3} \mathrm{Sn}_{2}$, then these two intermetallics react with nickel to form $\mathrm{Ni}_{3} \mathrm{Sn}$. For $T_{\max }=800^{\circ} \mathrm{C}$ estimated duration of chemical reaction is 5 minutes whereas for $T_{\max }=900^{\circ} \mathrm{C}$ the model predicts completion of chemical reactions after 30 seconds of exposure.

a)

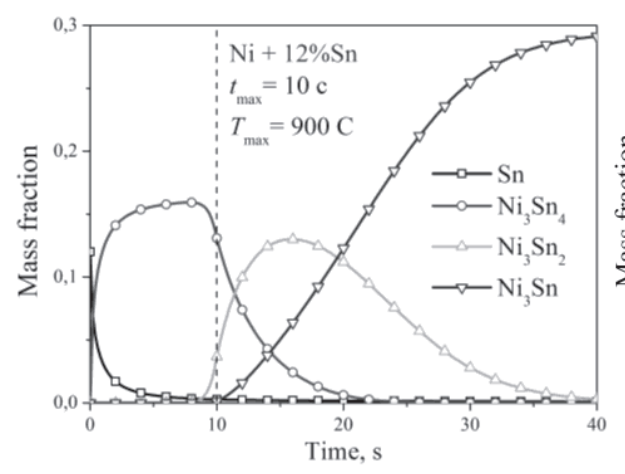

b)

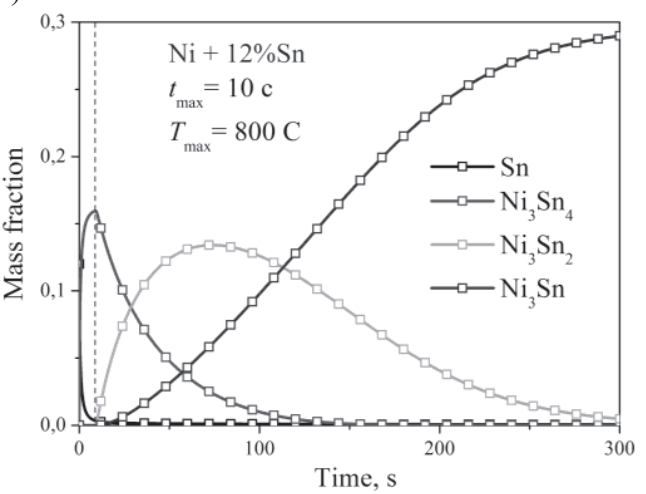

Fig. 3. Chemical reactions in Ni-Sn system when heated from $T_{0}=20^{\circ} \mathrm{C}$ to (a) $T_{\max }=800^{\circ} \mathrm{C}$ and (b) $T_{\max }=900^{\circ} \mathrm{C}$ for $t_{\max }=10$ seconds with subsequent exposure

For the experimental verification of the developed model, the microstructure and phase composition of two-component DCM binder Ni+12\% Sn produced by intensive electro sintering with a temperature profile close to (10) with $T_{\max }=900^{\circ} \mathrm{C}$ has been analyzed. Figure 4(a) shows microstructure of the partially sintered binder: dark color is nickel, bright color is tin, gray color is intermetallic layer $\mathrm{Ni}_{3} \mathrm{Sn}_{4}$, black color shows the pores. According to X-ray analysis, binder also contains about $4 \mathrm{wt} \%$ of $\mathrm{Ni}_{3} \mathrm{Sn}$. Sintering was intentionally interrupted after 12 seconds to capture evolution of the structure, including the thickness of the reaction layer (noteworthy, it is almost constant). The structure of the same binder sintered for 30 seconds is homogeneous and almost pore-free (fig. 4(b)). The X-ray microanalysis confirms that the reinforcing phase consists al- 
most entirely of intermetallic $\mathrm{Ni}_{3} \mathrm{Sn}$ which means completion of chemical reactions. These experimental data are quantitatively and qualitatively consistent with simulations that confirms the adequacy of the proposed model.

a)

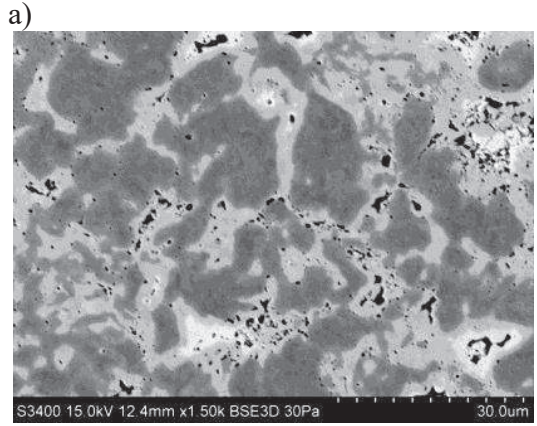

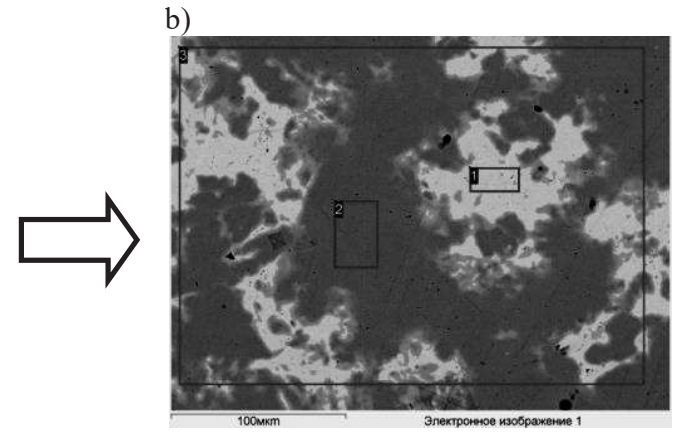

Fig. 4. Microstructure of the partially (after 12 seconds) and completely (after 30 seconds) sintered two-component binder $\mathrm{Ni}+12 \% \mathrm{Sn}$

\section{DCM characterization}

4.1. Thermal conductivity. For the tool-oriented DCM, reliable adhesive/chemical diamond-to-matrix bonding is particularly important because it determines the retention strength of diamonds and, hence, overall tool performance. Weak bonding worsens temperature regime of diamond grains and leads to their untimely dropping out of the working surface of a tool. There exists a strong correlation between the quality of thermal and mechanical contact because both are determined by the same physical and chemical processes at the interface. This fact is crucial for using the thermal conductivity as a DCM quality criterion.

It has been found that thermal conductivity of Ni-Sn binder significantly decreases with increasing volume fraction of intermetallic phase (fig. 5). DCM conductivity increases with increasing volume fraction of diamonds (fig. 6). Adding the adhesion-active components to the binder provides a significant improvement in the thermal and mechanical properties of DCM. Deposition of chromium on the surface of diamond increases effective thermal conductivity of diamond composite with $\mathrm{Ni}+6 \% \mathrm{Sn}$ binder by $15-25 \%$, that is a probable consequence of interface chemical reactions. The obtained data were interpreted with aid of the micromechanical model of composite with imperfect interface [14] predicting the effective thermal conductivity of composite as well as evaluating the interface contact conductivity by solving the inverse problem. It has been found that adding $\mathrm{Cr}$ increases the contact thermal conductivity of diamond-binder interface tenfold, from $2.1 \cdot 10^{6}$ to $2.3 \cdot 10^{7} \mathrm{~W} /\left(\mathrm{m}^{2} \cdot \mathrm{K}\right)$ [14] being typical value for chemical bonding case [15]. 


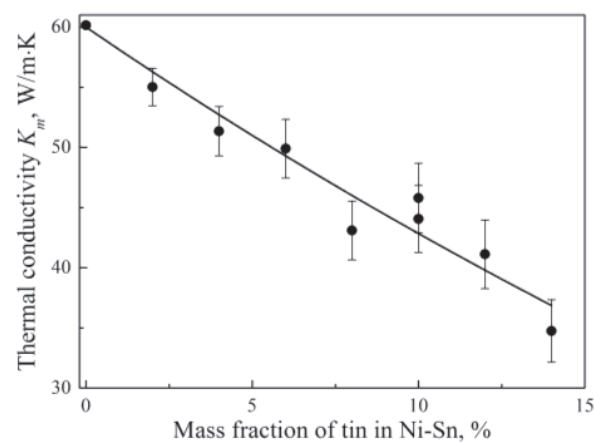

Fig. 5. Thermal conductivity of Ni-Sn binder: solid circles represent experimental data, solid curve is approximation

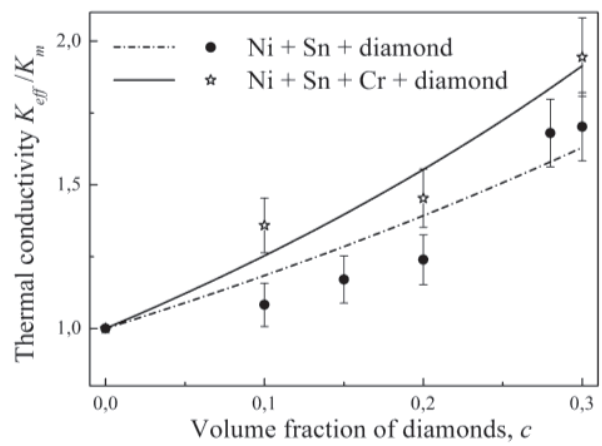

Fig. 6. - Thermal conductivity of DCM with $\mathrm{Ni}+6 \% \mathrm{Sn}$ binder (solid circles) and with adding $\mathrm{Cr}$ (open stars)

4.2. Deformation curve and hardness. The presence of tin significantly (up to 2.5 times for the $16 \% \mathrm{Sn}$ mass fraction) increases yield limit of binder. This is due to formation of the heterogeneous microstructure where the intermetallics play a role of hard reinforcing phase. In contrast to the binders obtained by conventional powder metallurgy methods or solid-phase IES, the studied samples do not exhaust the resource of plasticity even under strain in tens of percents. The curves in figures 5-7 show a significant hardening of the material, and therefore no significant residual stresses after IES the presence of a limited amount of liquid phase. Macro hardness and yield strength of Ni-Sn alloy increase with increasing fraction of intermetallics, see figure 8.

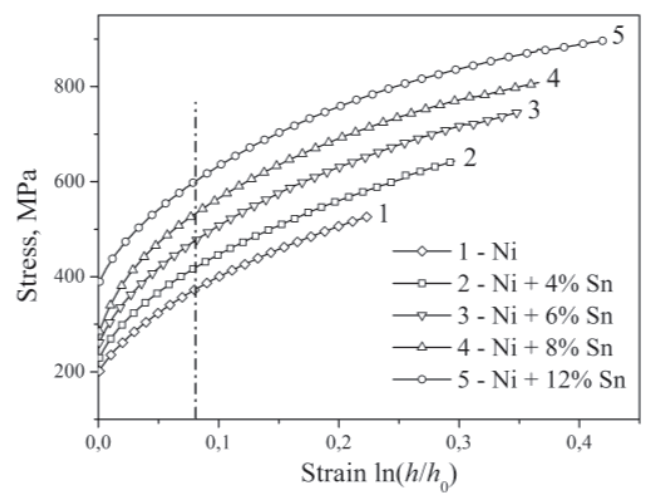

Fig. 7. Deformation curves of the electro sintered $\mathrm{Ni}$ and $\mathrm{Ni}-\mathrm{Sn}$ alloys

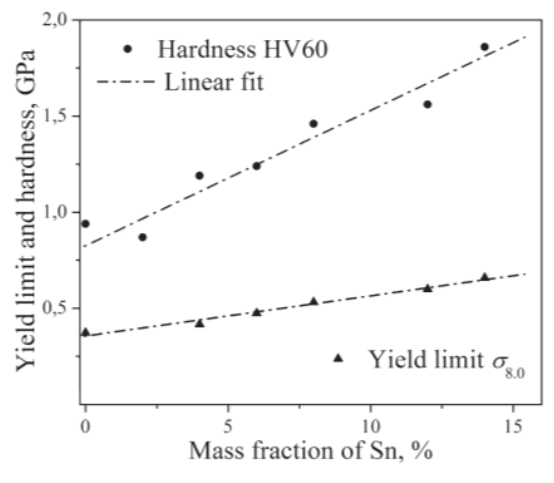

Fig. 8. Macro hardness and yield limit of $\mathrm{Ni}-\mathrm{Sn}$ alloys

4.3. Micro- and nanohardness. Micro and nanohardness of electro sintered DCM binder was conducted by the multiple indentation technique [16], which consists in conducting a series of tests (fig. 9) followed by statistical processing of the obtained indentation curves (fig. 10). 


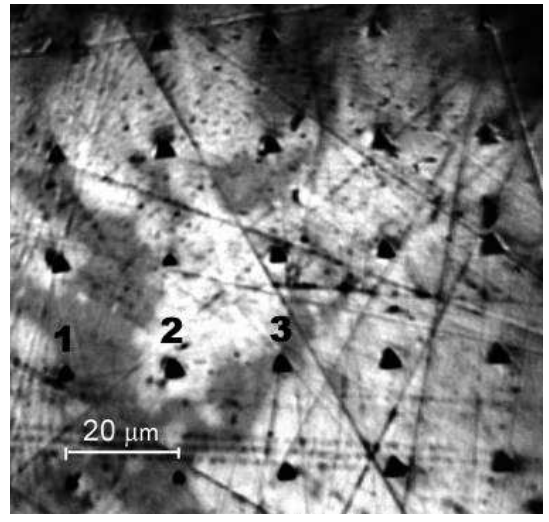

Fig. 9. Grid of indents in DCM binder Ni-6\% $\mathrm{Sn}$

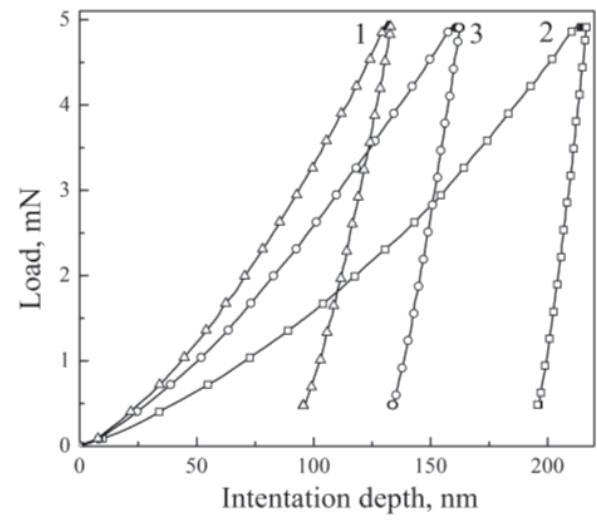

Fig. 10. Load - displacement curves for $\mathrm{Ni}$ (curve 1), $\mathrm{Ni}_{3} \mathrm{Sn}$ (curve 2) and their mixture (curve 3)

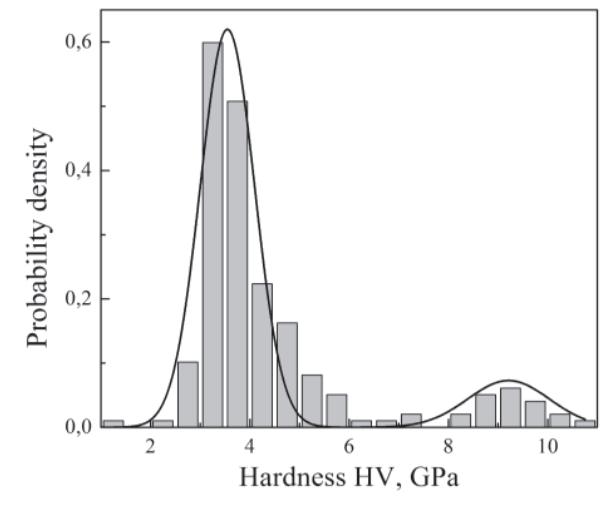

Fig. 11 - Hardness distribution of DCM binder $\mathrm{Ni}-6 \% \mathrm{Sn}$

Comparing the simulation results with experimental data on macro hardness (HV60), micro hardness (HV20g and HV200g) and nanohardness under load 5 $\mathrm{mN}$ (figs. 9-11) proves the substantial load-dependence of hardness. In particular, for $\mathrm{Ni}_{3} \mathrm{Sn}$ this technique predicts micro hardness HV200g $=2.4 \mathrm{GPa}$, HV20g in the range of 3.7 to $3.9 \mathrm{GPa}$ and nanohardness from 8.4 to $9.2 \mathrm{GPa}$ for $5 \mathrm{mN}$ load.

4.4. Fracture. In completion, we show some results of SEM study of DCM microstructure. In figure 12, the fracture surface of electro sintered DCM (400/315 AST160 diamonds, binder Ni+10\% Sn) is shown.

The fact that macro crack passed through the diamond crystals indicates that the strength of the diamond-to-matrix bond exceeds the tensile strength of diamond in the plane (111). On the other diamonds, the rests of binder are observed, especially on the faces (100). This is consistent with the available litera- 
ture data [17] on the contact interaction of nickel with diamond at $700^{\circ} \mathrm{C}$ and above with formation of the adhesive bond with strength of $300 \mathrm{MPa}$. The fracture behavior of binder is viscous in nickel and brittle in the intermetallic inclusions, see figure 13.

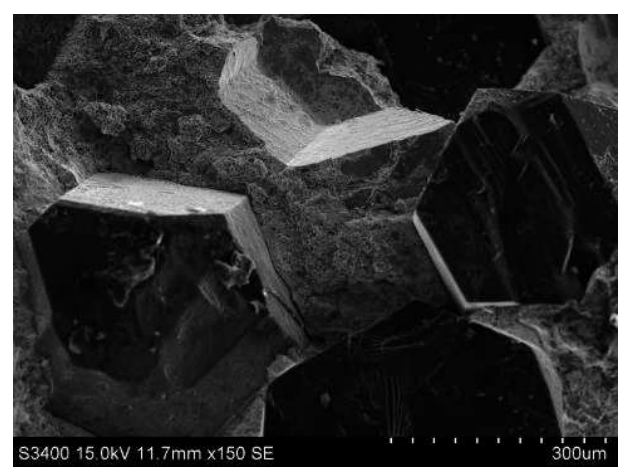

Fig. 12. Fracture surface of electrosintered DCM

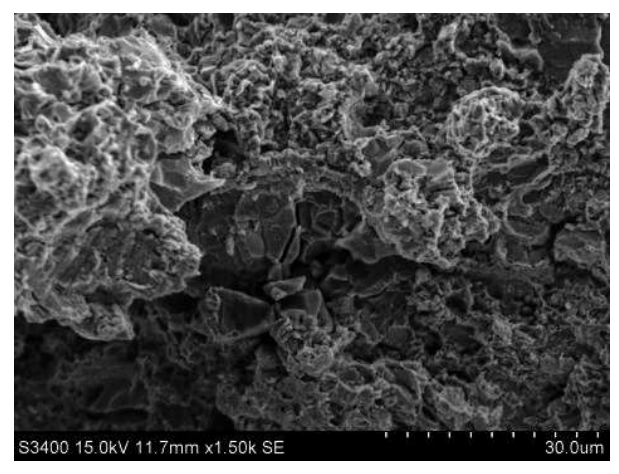

Fig. 13. Fracture surface of DCM binder

\section{Concluding remarks}

The advantages of using IES for DCM production are as follows. First, in contrast to conventional powder metallurgy technologies, consolidation of powder compacts takes units or tens of seconds at the sintering temperature of $850^{\circ} \mathrm{C}$ which excludes degradation of diamonds. Second, IES does not require renewable or protective atmosphere that simplifies greatly the manufacturing process. Third, the limited heating area and transience of process reduces energy consumption by an order as compared to traditional technologies. The presence of a limited amount of the liquid phase during the sintering results in significant improvement in physical and mechanical properties due to formation of specific heterogeneous microstructure with the intermetallic compounds acting as a hard reinforcing phase and significantly (by 2.5 times) increasing the hardness and yield limit of binder. What is important, the macro plasticity of DCM is retained: compressive deformation of $40 \%$ does not result in cracking or fracture patterns. The established correlations between the initial mixture composition and physico-mechanical properties of the material ensure producing by IES the pore-free structure of DCM and purposeful formation of its properties for the specific tool application. The above mentioned results constitute a scientific basis of the fast and energy-efficient industrial technology of the diamond tools manufacturing.

\section{Acknowledgement}

The research leading to these results has received funding from the People Programme (Marie Curie International Research Staff Exchange) of the European Union's Seventh Framework Programme FP7/2007-2013/ under REA grant agreement nº PIRSES-GA-2013-610547. 


\section{References}

[1] Maystrenko A.L., Ivanov S.A., Pereyaslov V.P., Voloshym M.N.: Intensive electro sintering of diamond-containing composite materials, J. Superhard Materials, 22 (2000), 36-42.

[2] Shmegera R.S., Kushch V.I., Maystrenko A.L.: Metal binder based on nickel for an intensive electro sintering of diamond-containing composites. J. Superhard Materials, 36 (2014) 393-400.

[3] Van Beek J.A., Stolbe S.A., van Loo F.J.J.: Multiphase diffusion in the systems Fe-Sn and Ni-Sn, Z. Metallkde, 73 (1982) 439-444.

[4] Schmetterer C., Flandorfer H., Richter K.W., et al.: A new investigation of the system Ni-Sn, Intermetallics, 15 (2007) 869-884.

[5] Eremenko V.N., Woodman N.D., Kostrova L.I., Verhovodov P.A.: Contact reaction at tin spreading in nickel. Powder metallurgy, 3 (1985) 31-34.

[6] Bader S., Gust W., Hieber H.: Rapid formation of intermetallic compaunds by interdiffusion in the $\mathrm{Cu}-\mathrm{Sn}$ and Ni-Sn systems, Acta Metall. Mater., 43 (1995) 329337.

[7] Klepser C.A.: Growth of Intermetallic Phases at Low Temperature, PhD Thesis, MIT, 1996.

[8] Dybkov V.I.: Reaction Diffusion and Solid State Chemical Kinetics, IPMS Publications, Kyiv 2013p.

[9] Gur D., Bamberger M.: Reactive isothermal solidification in the Ni-Sn system, Acta Materialia, 46 (1998) 4917-4923.

[10] Sorokova S.N., Knyazeva A.G.: Linked model of sintering Ti-TiAl3 powder systems, Bull. Tomsk Polytechnic Univ., 314 (2009) 96-101.

[11] Evstigneev N.K., Knyazeva A.G.: Choice of rheological models to describe the synthesis of the intermetallic compound, combined with extrusion through conical mold, PSTU Bulletin - Mechanics, 1 (2010) 59-71.

[12] Binnewies M., Milke E.: Thermochemical Data of Elements and Compounds, Wiley, Weinheim 2002.

[13] Hasselman, D.P.H. and Johnson, L.F.: Effective thermal conductivity of composites with interfacial thermal barrier resistance, J. Compos. Mater., 21 (1987) 508515.

[14] Shmegera R.S., Podoba Ya.O., Kushch V.I., Belyaev A.S.: Effect of the contact conductivity of the diamond-metal binder interface on the thermal conductivity of diamond-containing composites, J. Superhard Materials, 37 (2015) 242-252.

[15] Stoner R.J., Maris H.J., Anthony T.R., Banholzer W.F.: Measurements of the Kapitza conductance between diamond and several metals, Phys. Rev. Let., 68 (1992) 1563-1566.

[16] Kushch V.I., Dub S.N., Shmegera R.S., Sirota Yu.V., Tolmacheva G.N.: Procedure of the multiple indentations for determination of the hardness parameters of heterogeneous materials J. Superhard Materials, 37 (2015) 173-181.

[17] Bokhonov B.B.,Ukhina A.V., Dudina D.V., Gerasimov K.B., Anisimov A.G., Mali V.I.: Towards a better understanding of nickel/diamond interactions: the interface formation at low temperatures, RSC Advances, 5 (2015) 51799-51806. 


\section{INTENSYWNE SPIEKANIE OPOROWE KOMPOZYTÓW DIAMENTOWYCH ZE SPOIWEM WIELOSKLADNIKOWYM NA BAZIE} Ni-Sn

\section{Streszczenie}

Tematyka artykułu dotyczy intensywnego spiekania oporowego (ISO) diamentowych materiałów kompozytowych (DMK) ze spoiwem wieloskładnikowym na bazie Ni-Sn. Badano wpływ składu mieszanki proszku, domieszek aktywujących i parametrów technologicznych spiekania na tworzenie mikrostruktury oraz na właściwości fizyczne i mechaniczne DMK. Ustalono, że mechanizmy zachodzące podczas spiekania oporowego obejmują termicznie aktywowane odkształcenie plastyczne cząstek proszku niklu, topienie cyny oraz infiltrację i interakcje chemiczne składników. Obecność fazy ciekłej podczas spiekania oporowego zwiększa przewodność wypraski i intensywność nagrzewania, co z kolei znacznie zwiększa szybkość skurczu, wspomaga równomierne rozprowadzenie składników oraz powstawanie faz międzymetalicznych. Opracowano makrokinetyczny model powstawania faz międzymetalicznych w systemie Ni-Sn w warunkach nieizotermicznych oraz model diamentowego materiału kompozytowego z uporządkowaną osnową i fazą metaliczną. Przeprowadzono ocenę właściwości termicznych i mechanicznych diamentowego materiału kompozytowego spiekanego oporowo. Określono początkowy skład mieszanki oraz parametry technologiczne spiekania oporowego zapewniające odpowiednią jakość DMK. Zaproponowana metoda wytwarzania wierteł w procesie ISO stwarza potencjalną podstawę do przemysłowej technologii produkcji narzędzi diamentowych.

Słowa kluczowe: kompozyty diamentowe, skurcz, spiekanie, przewodność cieplna

DOI: $10.7862 / \mathrm{rm} .2016 .13$

Otrzymano/received: $12.05 .2016 r$

Zaakceptowano/accepted: 22.06.2016 r. 